\title{
MAXINE: A SPREADSHEET FOR ESTIMATING DOSE FROM CHRONIC ATMOSPHERIC RADIOACTIVE RELEASES
}

Ali A. Simpkins

Technical Reviewer

August 2002

Westinghouse Savannah River Company Savannah River Site

Aiken, SC 29808

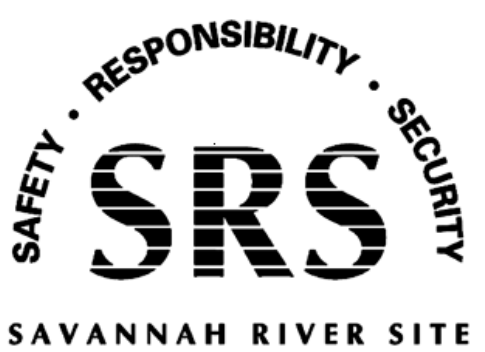


This document was prepared in conjunction with work accomplished under Contract No. DE-AC09-96SR18500 with the U. S. Department of Energy.

\section{DISCLAIMER}

This report was prepared as an account of work sponsored by an agency of the United States Government. Neither the United States Government nor any agency thereof, nor any of their employees, makes any warranty, express or implied, or assumes any legal liability or responsibility for the accuracy, completeness, or usefulness of any information, apparatus, product or process disclosed, or represents that its use would not infringe privately owned rights. Reference herein to any specific commercial product, process or service by trade name, trademark, manufacturer, or otherwise does not necessarily constitute or imply its endorsement, recommendation, or favoring by the United States Government or any agency thereof. The views and opinions of authors expressed herein do not necessarily state or reflect those of the United States Government or any agency thereof.

This report has been reproduced directly from the best available copy.

Available for sale to the public, in paper, from: U.S. Department of Commerce, National Technical Information Service, 5285 Port Royal Road, Springfield, VA 22161, phone: (800) 553-6847, fax: (703) 605-6900

email: orders@ntis.fedworld.gov

online ordering: http://www.ntis.gov/help/index.asp

Available electronically at http://www.osti.gov/bridge

Available for a processing fee to U.S. Department of Energy and its contractors, in paper, from: U.S. Department of Energy, Office of Scientific and Technical Information, P.O. Box 62, Oak Ridge, TN 37831-0062,

phone: (865)576-8401,

fax: (865)576-5728

email: $\underline{\text { reports@ adonis.osti.gov }}$ 
Key Words Dose Determination Atmospheric Releases

Retention: Lifetime

\title{
MAXINE: A SPREADSHEET FOR ESTIMATING DOSE FROM CHRONIC ATMOSPHERIC RADIOACTIVE RELEASES
}

\author{
A. A. Simpkins
}

Issued: August 2002

SRTC

SAVANNAH RIVER TECHNOLOGY CENTER

AIKEN, SC 29808

Westinghouse Savannah River Company Savannah River Site Aiken, SC 29808

PREPARED FOR THE U.S. DEPARTMENT OF ENERGY UNDER CONTRACT NO. DE-AC09-96SR18500 
ABSTRACT

MAXINE is an EXCELC spreadsheet, which is used to estimate dose to individuals for routine atmospheric releases of radioactive materials. MAXINE does not contain an atmospheric dispersion model, but rather doses are estimated using air and ground concentrations as input. Minimal input is required to run the program and site specific parameters are used when possible. Complete code description, verification of models, and user's manual have been included. 
TABLE OF CONTENTS

1. INTRODUCTION

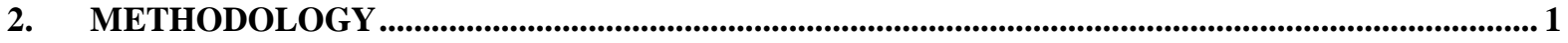

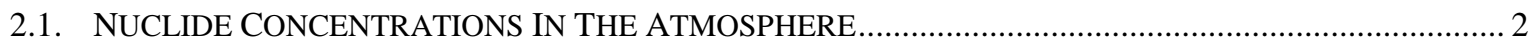

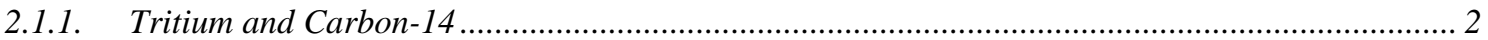

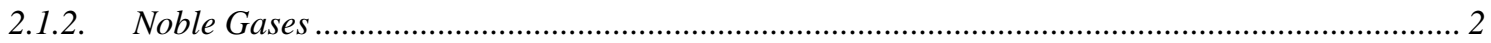

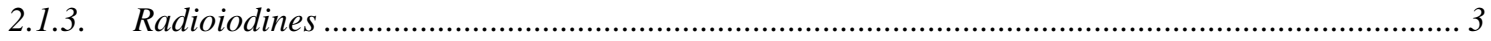

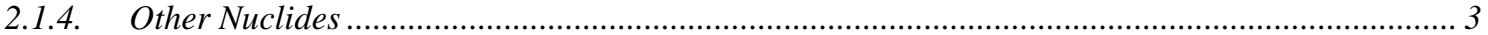

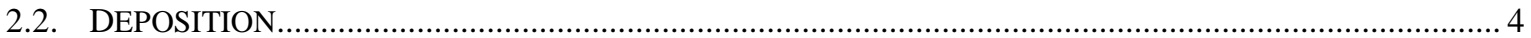

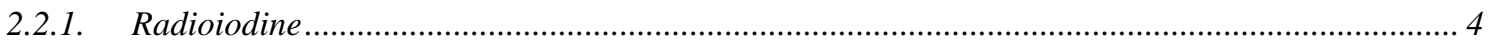

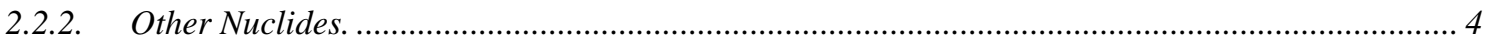

2.3. NUCLIDE CONCENTRATION IN VEGETATION .............................................................4

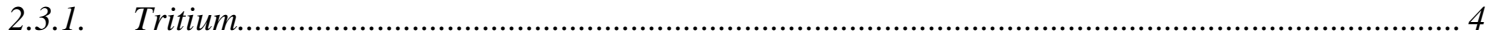

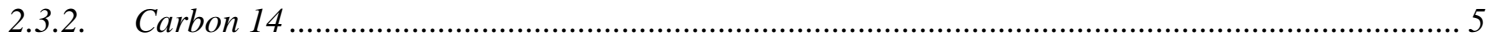

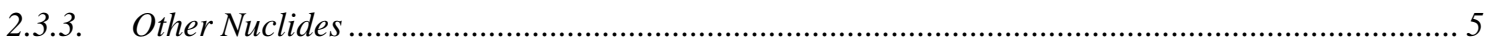

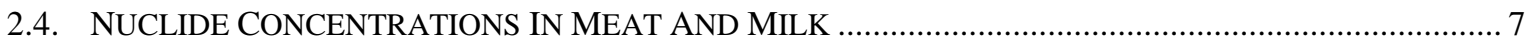

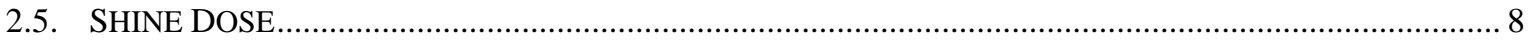

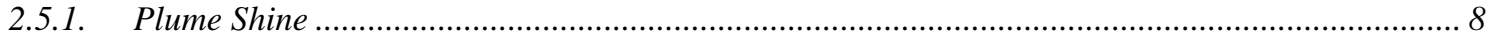

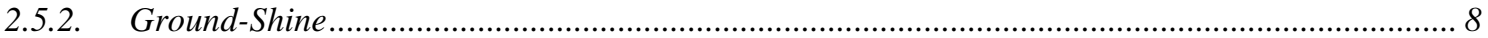

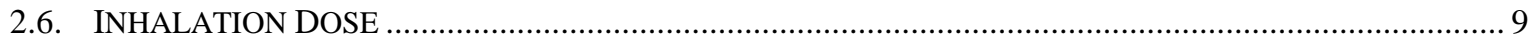

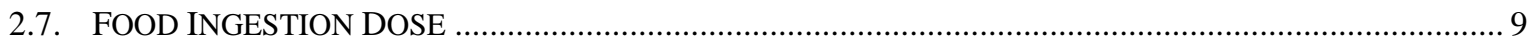

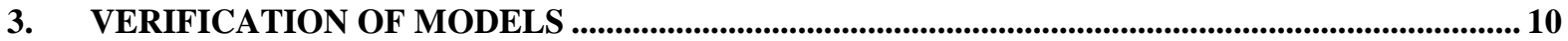

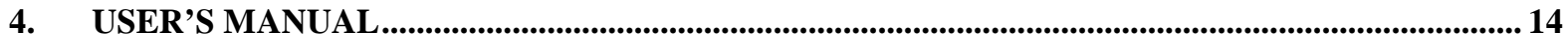

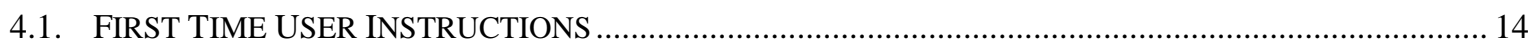

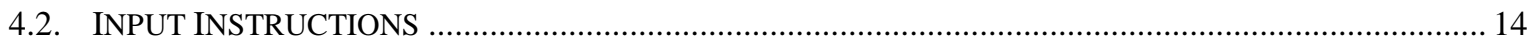

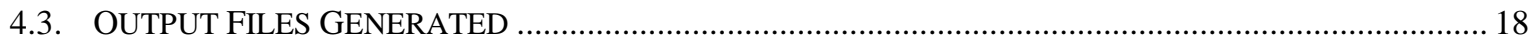

5. CONCLUSIONS........................................................................................................................................... 18

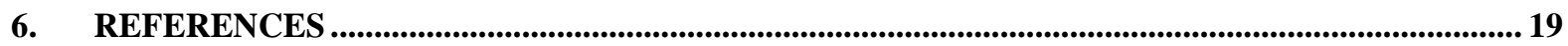




\section{LIST OF TABLES}

TABLE 1. DEFAULT PARAMETERS USED FOR VEGETATION CONCENTRATION

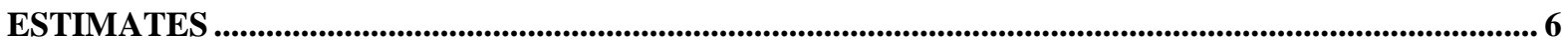

TABLE 2. DEFAULT PARAMETERS USED FOR MEAT AND MILK CONCENTRATION

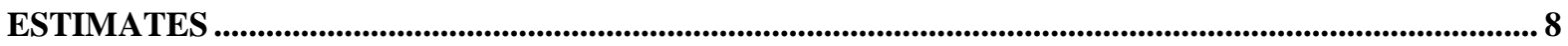

TABLE 3. CONSUMPTION PARAMETERS (HAMBY 1991) .................................................................. 10

TABLE 4. INPUT PARAMETERS FOR EXPANDED TEST CASE ...................................................11

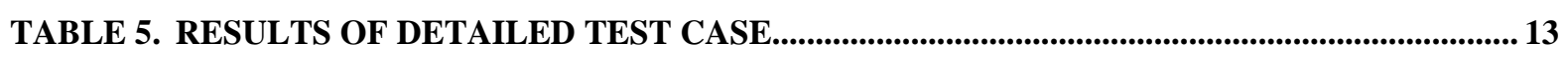

TABLE 6. COMPARISON OF MAXDOSE-SR TEST CASES WITH MAXINE ........................................ 14

TABLE 7. COMPARISON OF MAXINE WITH HAND CALCULATIONS.......................................... 14 


\title{
MAXINE: A SPREADSHEET FOR ESTIMATING MAXIMUM INDIVIDUAL DOSE FROM CHRONIC ATMOSPHERIC RADIOACTIVE RELEASES
}

\author{
By A. A. Simpkins \\ Westinghouse Savannah River Company \\ Savannah River Site \\ Aiken, SC 29808
}

\section{INTRODUCTION}

MAXINE is an EXCEL(C) spreadsheet that estimates dose to exposed individuals following routine releases of radioactive materials to the atmosphere. MAXINE employs the methods contained in MAXDOSE-SR (Simpkins 1999). Both MAXINE and MAXDOSE-SR follow U.S. Nuclear Regulatory Commission Regulatory (U.S. NRC) Guide 1.109 (USNRC 1977a) which details how to estimate dose from routine releases. For specified air and ground concentrations, MAXINE will determine the potential dose to exposed individuals. Exposure pathways include 1) inhalation; 2) ground and plume shine; and 3) ingestion of meat, milk, and vegetables.

Verification of MAXINE includes comparisons with the verified code MAXDOSE-SR as well as hand calculations. A complete description of the spreadsheet and user's manual have also been included. The spreadsheet version is useful in the fact that it allows for the determination of dose at distances other than the site boundary. Also, it is convenient for use with uncertainty software such as Crystal Ball@.

\section{METHODOLOGY}

The methodology basis for the dosimetry portion of MAXDOSE-SR and MAXINE is the GASPAR code (Eckerman et. al. 1980) which was written in 1977 by Oak Ridge National Laboratory for the U. S. NRC. The models in GASPAR calculate atmospheric concentrations, deposition rates, concentrations in foodstuffs, and radiation dose to individuals resulting from chronic releases of radionuclides to the atmosphere.

MAXINE needs the following relative air and ground deposition values for proper execution of the spreadsheet: 1 ) relative air concentration, $\chi / Q$; 2) relative air concentration decayed by 2.26 days, $\left.\chi_{\mathrm{D}} / \mathrm{Q} ; 3\right)$ relative air concentration decayed and depleted for 8 days, $\chi_{\mathrm{DD}} / \mathrm{Q}$; and 4 ) relative deposition, D/Q. These can all be taken from MAXDOSE-SR output or derived using the methodologies contained within U.S. NRC Regulatory Guide 1.111 (USNRC 1977b). These concentrations are used to calculate concentrations in various media and ultimately dose. Concentrations in various media are determined differently based on the radionuclide of interest. The following discusses how the concentration in each media is estimated. 


\subsection{Nuclide Concentrations In The Atmosphere}

\subsubsection{Tritium and Carbon-14}

Downwind atmospheric concentrations, $\chi_{\mathrm{i}}$, of tritium and carbon-14 are estimated using

$$
\chi_{\mathrm{i}}=\frac{\chi}{\mathrm{Q}} \bullet \mathrm{Q}_{\mathrm{i}} \bullet 10^{6} \frac{\mu \mathrm{Ci}}{\mathrm{Ci}} \cdot 3.17 \times 10^{-8} \frac{\mathrm{yr}}{\mathrm{s}}
$$

where

$\chi_{\mathrm{i}} \quad$ air concentration, $\mu \mathrm{Ci} / \mathrm{m}^{3}$

$\frac{\chi}{\mathrm{Q}} \quad$ relative air concentration, $\mathrm{s} / \mathrm{m}^{3}$

$\mathrm{Q}_{\mathrm{i}} \quad$ release amount by radionuclide, $\mathrm{Ci} / \mathrm{yr}$

Since both tritium and carbon-14 have relatively long half-lives, radiological decay is not taken into account when estimating downwind concentration for these nuclides.

\subsection{2.___Noble Gases}

Air concentrations of noble gases are estimated by,

$$
\chi_{\mathrm{i}}=\frac{\chi}{\mathrm{Q}} \bullet \mathrm{Q}_{\mathrm{i}} \cdot 10^{6} \cdot 3.17 \times 10^{-8} \frac{\mathrm{yr}}{\mathrm{s}} \bullet \mathrm{e}^{-\lambda_{\mathrm{i}} \mathrm{t}}
$$

where the exponential accounts for radioactive decay during transit to the receptor. The parameter $t$ is the average time required for the effluent to reach the receptor and all other terms have been previously defined. The decayed $\chi / \mathrm{Q}$ is obtained by assuming the effluent is radioactive with a half-life of 2.26 days (USNRC 1977b). The value of $t$ is found by solving the radioactive decay equation used to calculate a 2.26-day decayed relative air concentration,

$$
\frac{\chi_{\mathrm{D}}}{\mathrm{Q}}=\frac{\chi}{\mathrm{Q}} \mathrm{e}^{-\left(112 \mathrm{yr}^{-1}\right) \mathrm{t}}
$$

where the value $112 \mathrm{yr}^{-1}$ is the decay constant for a 2.26 day half-life. The plume travel time (in years) is then, 


$$
\mathrm{t}=\frac{\ln \left(\frac{\chi_{\mathrm{D}} / \mathrm{Q}}{\chi / \mathrm{Q}}\right)}{\left(\frac{\ln 2 \cdot 365 \mathrm{~d}}{2.26 \mathrm{~d} \cdot 1 \mathrm{yr}}\right)}
$$

\subsection{3._Radioiodines}

Radioiodine concentrations in the atmosphere are determined using,

$$
\chi_{\mathrm{i}}=\left\{\frac{\chi}{\mathrm{Q}} \bullet\left(1-\mathrm{F}_{\mathrm{I}}\right)+\frac{\chi_{\mathrm{DD}}}{\mathrm{Q}} \bullet \mathrm{F}_{\mathrm{I}} \bullet \mathrm{e}^{31.62 \mathrm{t}}\right\} \bullet \mathrm{Q}_{\mathrm{i}} \bullet \mathrm{e}^{-\lambda_{\mathrm{i}} \mathrm{t}}
$$

where

$\chi / \mathrm{Q} \quad$ relative air concentration, $\mathrm{s} / \mathrm{m}^{3}$

$\chi_{\mathrm{DD}} / \mathrm{Q} \quad$ decayed and depleted concentration, $\mathrm{s} / \mathrm{m}^{3}$

$\mathrm{F}_{\mathrm{I}} \quad$ fraction of iodine that is elemental, unitless

The factor in brackets calculates a weighted relative air concentration accounting for the deposition of the elemental fraction. The positive rate coefficient (31.62) negates decay from the generic 8-day half-life that was already applied to the decayed and depleted $\chi / Q$. An exponential term is also included in this equation to account for the actual radioactive decay during plume transit.

\subsubsection{Other Nuclides}

Air concentrations of the remaining nuclides (those not considered above) are calculated using

$$
\chi_{\mathrm{i}}=\frac{\chi_{\mathrm{DD}}}{\mathrm{Q}} \bullet \mathrm{Q}_{\mathrm{i}} \cdot 10^{6} \bullet 3.17 \times 10^{-8} \frac{\mathrm{yr}}{\mathrm{s}} \bullet \mathrm{e}^{\left(31.62-\lambda_{\mathrm{i}}\right) \mathrm{t}}
$$

where all terms have been defined previously. Again, the positive rate coefficient in the exponential term (31.62 $\left.\mathrm{yr}^{-1}\right)$ negates the decay from the 8-day half-life that was already applied to the decayed and depleted $\chi / \mathrm{Q}$. 


\subsection{Deposition}

Deposition rates are estimated from relative deposition values based on the type of radionuclide.

\subsection{1._Radioiodine}

Deposition rates, $\mathrm{d}_{\mathrm{i}}$, of iodine radioisotopes are estimated using,

$$
\mathrm{d}_{\mathrm{i}}=\frac{\mathrm{D}}{\mathrm{Q}} \bullet \mathrm{Q}_{\mathrm{i}} \bullet \mathrm{F}_{\mathrm{I}} \bullet 10^{6} \bullet \mathrm{e}^{-\left(31.62-\lambda_{\mathrm{i}}\right) \mathrm{t}}
$$

where

$\mathrm{D} / \mathrm{Q} \quad$ relative deposition value, $1 / \mathrm{m}^{2}$

$\mathrm{Q}_{\mathrm{i}} \quad$ radionuclide release rate, $\mathrm{Ci} / \mathrm{yr}$

$\mathrm{F}_{\mathrm{I}} \quad$ fraction of iodine assumed to be elemental, unitless

$\lambda_{\mathrm{i}} \quad$ nuclide-specific decay constant, $\mathrm{yr}^{-1}$

$\mathrm{t}$ plume travel time from the source to the receptor, $\mathrm{yr}$

\subsubsection{Other Nuclides.}

Deposition rates for all remaining nuclides are determined using

$$
\mathrm{d}_{\mathrm{i}}=\frac{\mathrm{D}}{\mathrm{Q}} \bullet \mathrm{Q}_{\mathrm{i}} \bullet 10^{6} \bullet \mathrm{e}^{\left(31.62-\lambda_{\mathrm{i}}\right) \mathrm{t}}
$$

where all parameters have been previously defined. Deposition is modeled for all radionuclides, except for tritium, carbon-14 and noble gases.

\subsection{Nuclide Concentration In Vegetation}

\subsection{1. $\quad$ Tritium}

A specific activity model describes the uptake of tritium in vegetation. Tritium concentration in vegetation is determined directly from the concentration of tritium in atmospheric moisture. Equilibrium is assumed to be achieved in a short time relative to an annual release. The concentration of tritium in vegetation, $\mathrm{C}_{\mathrm{T}}^{\mathrm{V}}$, is determined by

$$
\mathrm{C}_{\mathrm{T}}^{\mathrm{V}}=\frac{\chi_{\mathrm{T}} \bullet 0.75 \bullet 0.5}{\mathrm{H}}
$$


where

$\mathrm{C}_{\mathrm{T}}^{\mathrm{V}} \quad$ concentration in vegetation, $\mu \mathrm{Ci} / \mathrm{g}$

$\chi_{\mathrm{T}} \quad$ atmospheric concentration, $\mu \mathrm{Ci} / \mathrm{m}^{3}$

0.75 fraction of plant mass that is water, unitless

0.5 concentration ratio of plant tritium to atmospheric tritium, unitless

$\mathrm{H} \quad$ annual average absolute humidity (11 g/m $\mathrm{m}^{3}$ for SRS) (Hamby 1990)

Studies (Bauer and Hamby 1993, Hamby 1993) have shown that dose estimates for the vegetation consumption pathway are sensitive to the parameters in this model. Therefore, a site-specific value was determined for the plant-tritium-to-atmospheric-tritium model (Hamby and Bauer 1994).

\subsubsection{Carbon 14}

The carbon-14 model for vegetation concentration is similar to the tritium model. The following equation is used to estimate the concentration:

$$
\mathrm{C}_{\mathrm{C}}^{\mathrm{V}}=\frac{\chi_{\mathrm{c}} \bullet \mathrm{F}_{\mathrm{t}} \bullet 0.11}{0.00016}
$$

where

$\chi_{c} \quad$ atmospheric concentration, $\mu \mathrm{Ci} / \mathrm{m}^{3}$

$\mathrm{F}_{\mathrm{t}} \quad$ fraction equilibrium ratio

0.11 fraction of total plant mass that is natural carbon, unitless

$0.00016 \quad$ concentration of natural carbon in the atmosphere, unitless

\subsection{3._. Other Nuclides}

The concentration of other nuclides in vegetation is determined using

$$
\mathrm{C}_{\mathrm{i}}^{\mathrm{V}}=\mathrm{d}_{\mathrm{i}} \bullet\left[\frac{\mathrm{r}_{\mathrm{i}}\left(1-\mathrm{e}^{-\lambda_{\mathrm{i}}^{\mathrm{w}} \mathrm{t}_{\mathrm{e}}}\right)}{\mathrm{Y}_{\mathrm{v}} \lambda_{\mathrm{i}}^{\mathrm{w}}}+\frac{\mathrm{B}_{\mathrm{i}}^{\mathrm{v}}\left(1-\mathrm{e}^{-\lambda_{\mathrm{i}} \mathrm{t}_{\mathrm{b}}}\right)}{\mathrm{P} \bullet \lambda_{\mathrm{i}}}\right] \bullet \mathrm{e}^{-\lambda_{\mathrm{i}} \mathrm{t}_{\mathrm{h}}}
$$

where

$\mathrm{d}_{\mathrm{i}} \quad$ deposition rate, $\mathrm{Ci} / \mathrm{m}^{2} \mathrm{yr}$ 
$r_{i} \quad$ fraction of the nuclide deposited that remains on the surface of the plant, unitless

$\lambda_{\mathrm{i}}^{\mathrm{w}} \quad$ decay constant representing both weathering and radioactive losses, $1 / \mathrm{yr}$

$\mathrm{t}_{\mathrm{e}} \quad$ crop exposure time, $\mathrm{yr}$

$\mathrm{Y}_{\mathrm{v}} \quad$ crop productivity, $\mathrm{kg} / \mathrm{m}^{2}$

$\mathrm{B}_{\mathrm{i}}^{\mathrm{v}} \quad$ element-specific soil/plant uptake ratio, unitless

$\lambda_{\mathrm{i}} \quad$ radioactive decay constant, $1 / \mathrm{yr}$

$\mathrm{t}_{\mathrm{b}} \quad$ time over which the buildup of radionuclides occurs, $\mathrm{yr}$

P surface soil density, $\mathrm{kg} / \mathrm{m}^{2}$

$\mathrm{t}_{\mathrm{h}} \quad$ hold-up time after harvest (allows for decay before consumption), yr

The first and second expressions in the brackets account for contamination via foliar deposition and root uptake, respectively. All particulate nuclides are assumed to be fully retained on vegetation $(\mathrm{r}=1)$ while only $20 \%$ of the iodines are retained $(\mathrm{r}=0.2)$. The loss constant, $\lambda_{\mathrm{i}}^{\mathrm{w}}$ accounts for losses through physical weathering (14 day half-life) and radioactive decay. Values of $Y_{v}, t_{e}$, and $t_{h}$ vary depending on the type of crop and whether the vegetation is for human consumption or is to be used as fodder.

Concentrations in four types of vegetation are calculated in MAXINE. These four types along with their associated default parameter values are given in Table 1. These values are taken from Hamby (1991) and USNRC (1977a). Noble gases are assumed not to concentrate or deposit on vegetation.

Table 1. Default Parameters used for Vegetation Concentration Estimates

\begin{tabular}{|l|l|l|l|l|}
\hline Parameter & $\begin{array}{l}\text { Other } \\
\text { Vegetables }\end{array}$ & $\begin{array}{l}\text { Leafy } \\
\text { Vegetables }\end{array}$ & $\begin{array}{l}\text { Pasture } \\
\text { Grass }\end{array}$ & $\begin{array}{l}\text { Stored } \\
\text { Feed }\end{array}$ \\
\hline $\mathrm{r}($ iodines $)$ & 0.2 & same & same & same \\
$\mathrm{r}($ particulates $)$ & 1.0 & same & same & same \\
$\left.\lambda_{\mathrm{i}}(\mathrm{yr})^{-1}\right)$ & $18.07+\lambda_{\mathrm{i}}$ & same & same & same \\
$\mathrm{t}_{\mathrm{e}}(\mathrm{yr})$ & 0.192 & 0.192 & 0.0822 & 0.192 \\
$\mathrm{Y}_{\mathrm{v}}\left(\mathrm{kg} / \mathrm{m}^{2}\right)$ & 0.7 & 0.7 & 1.8 & 0.7 \\
$\mathrm{~B}_{\mathrm{i}}$ & element specific & same & same & same \\
$\lambda_{\mathrm{i}}\left(\mathrm{yr}{ }^{-1}\right)$ & nuclide specific & same & same & same \\
$\mathrm{t}_{\mathrm{b}}(\mathrm{yr})$ & scenario specific & same & same & same \\
$\mathrm{P}\left(\mathrm{kg} / \mathrm{m}^{2}\right)$ & 240 & same & same & same \\
\hline
\end{tabular}




\begin{tabular}{|l|l|l|l|l|}
\hline $\mathrm{t}_{\mathrm{b}}(\mathrm{yr})$ & 0.164 & 0.00274 & 0 & 0.247 \\
\hline
\end{tabular}

\subsection{Nuclide Concentrations In Meat And Milk}

Concentrations of radionuclides in meat and milk are determined from feed concentrations, fodder intake rates, and element-specific feed-to-meat/feed-to-milk transfer factors. The equations for meat and milk concentration estimates are essentially identical with the exception of feed transfer coefficient. Concentrations are estimated using,

$$
\begin{aligned}
& \mathrm{C}_{\mathrm{i}}^{\text {meat }}=\mathrm{C}_{\mathrm{i}}^{\text {fodder }} \bullet \mathrm{F}_{\mathrm{i}}^{\mathrm{b}} \bullet \mathrm{Q}_{\mathrm{F}} \bullet \mathrm{e}^{-\lambda_{\mathrm{i}} \mathrm{t}_{\mathrm{s}}} \\
& \mathrm{C}_{\mathrm{i}}^{\text {milk }}=\mathrm{C}_{\mathrm{i}}^{\text {fodder }} \bullet \mathrm{F}_{\mathrm{i}}^{\mathrm{m}} \bullet \mathrm{Q}_{\mathrm{F}} \bullet \mathrm{e}^{-\lambda_{\mathrm{i}} \mathrm{t}_{\mathrm{f}}}
\end{aligned}
$$

where

$\mathrm{C}_{\mathrm{i}}^{\text {fodder }} \quad$ nuclide concentration in cattle feed (determined below), $\mathrm{Ci} / \mathrm{kg}$

$\mathrm{F}_{\mathrm{i}}^{\mathrm{b}}$ and $\mathrm{F}_{\mathrm{i}}^{\mathrm{m}} \quad$ feed transfer coefficients for beef cow and milk cow, respectively, $\mathrm{d} / \mathrm{kg}$ or $\mathrm{d} / \mathrm{l}$

$\mathrm{Q}_{\mathrm{F}} \quad$ cattle feed rate, $\mathrm{kg} / \mathrm{d}$

$\mathrm{t}_{\mathrm{s}}$ and $\mathrm{t}_{\mathrm{f}} \quad$ transport time for meat and milk, respectively, yr

Values for these parameters are listed in Table 2 as taken from Hamby (1991).

The nuclide concentration in fodder is based on the fraction of time cattle spend on pasture and the fraction of that time that is spent consuming fresh pasture grass. The following equation calculates fodder concentration by weighting the concentration of pasture grass and stored feed.

$$
\mathrm{C}_{\mathrm{i}}^{\text {fodder }}=\mathrm{f}_{\mathrm{p}} \mathrm{f}_{\mathrm{s}} \mathrm{C}_{\mathrm{i}}^{\mathrm{p}}+\left[\mathrm{f}_{\mathrm{p}}\left(1-\mathrm{f}_{\mathrm{s}}\right)+\left(1-\mathrm{f}_{\mathrm{p}}\right)\right] \mathrm{C}_{\mathrm{i}}^{\mathrm{s}}
$$

$\mathrm{C}_{\mathrm{i}}^{\mathrm{p}} \quad$ concentration in pasture grass, $\mathrm{Ci} / \mathrm{kg}$

$\mathrm{C}_{\mathrm{i}}^{\mathrm{s}} \quad$ concentration in stored feed, $\mathrm{Ci} / \mathrm{kg}$

$f_{p} \quad$ fraction of time cattle spend on pasture, unitless

$\mathrm{f}_{\mathrm{s}} \quad$ fraction of time that cattle eat fresh grass while on pasture, unitless

Concentration of nuclides in goat's milk are determined in the same manner as cow's milk and beef except using different values (see Table 2) for feed consumption rate and the fraction of time spent on pasture and eating pasture grass. 
Table 2. Default Parameters used for Meat and Milk Concentration Estimates

\begin{tabular}{|l|c|c|c|}
\hline Parameter & Meat & Milk (cow) & Milk (goat) \\
\hline Feed consumption rated (kg/d) & 44 & 44 & 6 \\
Milking/Slaughter to consumption (d) & 6 & 2 & 2 \\
Fraction of year on pasture & 1.00 & 1.00 & 0.79 \\
Fraction intake from pasture* & 0.75 & 0.56 & 0.85 \\
\hline
\end{tabular}

*while on pasture

\subsection{Shine Dose}

\subsubsection{Plume Shine}

Dose to individuals from plume shine is estimated in MAXINE only for noble gases. The gamma dose from a particular noble gas in the atmospheric plume is calculated by

$$
\mathrm{D}_{\mathrm{i}}^{\mathrm{p}}=\chi_{\mathrm{i}} \bullet \mathrm{SF} \bullet \mathrm{DF}_{\mathrm{i}}^{\mathrm{p}} \bullet 1 \mathrm{yr}
$$

where

$\chi_{\mathrm{i}} \quad$ atmospheric concentration, $\mu \mathrm{Ci} / \mathrm{m}^{3}$

SF shielding factor accounting for the fraction of time spent indoors $(0.7$ for individuals), unitless

$\mathrm{DF}_{\mathrm{i}}^{\mathrm{p}} \quad$ nuclide specific plume-shine dose factor, mrem $\mathrm{m}^{3} / \mathrm{yr} \mu \mathrm{Ci}$ (USDOE 1988a)

\subsubsection{Ground-Shine}

Ground-shine doses are calculated for all particulate, gamma-emitting nuclides. The dose accounts for buildup over the plant lifetime and is given by,

$$
\mathrm{D}_{\mathrm{i}}^{\mathrm{g}}=\mathrm{d}_{\mathrm{i}} \bullet \mathrm{SF} \bullet \mathrm{DF}_{\mathrm{i}}^{\mathrm{g}} \bullet \frac{1-\mathrm{e}^{-\lambda_{\mathrm{i}} \mathrm{t}_{\mathrm{b}}}}{\lambda_{\mathrm{i}}} \bullet 1 \mathrm{yr}
$$

where

$\mathrm{DF}_{\mathrm{i}}^{\mathrm{g}} \quad$ nuclide-specific ground-shine dose factor, mrem $\mathrm{m}^{2} / \mathrm{yr} \mu \mathrm{Ci}$ (USDOE 1988a) All other parameters have been previously defined. 


\subsection{Inhalation Dose}

Inhalation dose is determined for individuals assuming a constant breathing rate and a constant concentration throughout the year of exposure. The nuclide-specific dose is estimated by,

$$
\mathrm{D}_{\mathrm{h}}^{\mathrm{inh}}=\chi_{\mathrm{i}} \bullet \mathrm{BR} \bullet \mathrm{DF}_{\mathrm{i}}^{\mathrm{inh}} \bullet 1000\left[\frac{\mathrm{mrem}}{\text { rem }}\right] \bullet 1 \mathrm{yr}
$$

where

$\chi_{\mathrm{i}} \quad$ atmospheric concentration, $\mu \mathrm{Ci} / \mathrm{m}^{2}$

BR breathing rate, $8000 \mathrm{~m}^{3} / \mathrm{yr}$ (USNRC 1977a)

$\mathrm{DF}_{\mathrm{i}}^{\mathrm{inh}} \quad$ nuclide specific dose conversion factor, rem/ $\mu \mathrm{Ci}$ (USDOE 1988b)

\subsection{Food Ingestion Dose}

Dose to an individual is estimated for ingestion of foodstuffs including vegetables, meat, and milk. Two categories of vegetables are available for consumption: "leafy" or "other." The "other" category includes fruits, grains, produce, and below ground vegetables. The dose via vegetable consumption for a one-year period is calculated using,

$$
\mathrm{D}_{\mathrm{i}}^{\mathrm{veg}}=\left[\mathrm{C}_{\mathrm{i}}^{\mathrm{v}} \mathrm{U}^{\mathrm{v}} \mathrm{f}_{\mathrm{v}}+\mathrm{C}_{\mathrm{i}}^{1} \mathrm{U}^{1} \mathrm{f}_{1}\right] \bullet \mathrm{DF}_{\mathrm{i}}^{\mathrm{ing}} \bullet 1000 \frac{\mathrm{mrem}}{\text { rem }} \bullet 1 \mathrm{yr}
$$

where

$\mathrm{C}_{\mathrm{i}} \quad$ radionuclide concentrations in leafy (l) or other vegetables $(\mathrm{v}), \mu \mathrm{Ci} / \mathrm{kg}$

$\mathrm{U}$ consumption rates of the two vegetable classifications (see Table 3), $\mathrm{kg} / \mathrm{yr}$

f fraction of two vegetable classifications that are home grown, unitless

DF nuclide specific dose conversion factor, $\mathrm{rem} / \mu \mathrm{Ci}$ (USDOE $1988 \mathrm{~b}$ )

Individual dose from meat and milk consumption is calculated in the same manner, using the equations 


$$
\begin{aligned}
& \mathrm{D}_{\mathrm{i}}^{\text {meat }}=\mathrm{C}_{\mathrm{i}}^{\text {meat }} \bullet \mathrm{U}^{\mathrm{f}} \bullet \mathrm{DF}_{\mathrm{i}}^{\mathrm{ing}} \bullet 1000 \frac{\mathrm{mrem}}{\text { rem }} \bullet 1 \mathrm{yr} \\
& \mathrm{D}_{\mathrm{i}}^{\text {milk }}=\mathrm{C}_{\mathrm{i}}^{\text {milk }} \bullet \mathrm{U}^{\mathrm{m}} \bullet \mathrm{DF}_{\mathrm{i}}^{\mathrm{ing}} \bullet 1000 \frac{\text { mrem }}{\text { rem }} \bullet 1 \mathrm{yr}
\end{aligned}
$$

Default usage factors for vegetables, meat, and milk are shown in Table 3 for maximum and average individuals.

Table 3. Consumption Parameters (Hamby 1991)

\begin{tabular}{|l|c|c|}
\hline & \multicolumn{2}{|c|}{ Consumption Rate } \\
\hline Parameter & Maximum & Average \\
\hline Vegetables & $276 \mathrm{~kg} / \mathrm{yr}$ & $163 \mathrm{~kg} / \mathrm{yr}$ \\
Meat & $81 \mathrm{~kg} / \mathrm{yr}$ & $43 \mathrm{~kg} / \mathrm{yr}$ \\
Milk & $230 \mathrm{~L} / \mathrm{yr}$ & $120 \mathrm{~L} / \mathrm{yr}$ \\
\hline
\end{tabular}

\section{VERIFICATION OF MODELS}

To verify MAXINE, comparisons were made with MAXDOSE-SR, which has been fully verified (Simpkins 1999). First a detailed comparison was made using all radionuclides available within MAXINE. The input for this detailed test case is shown in Table 4. For each pathway, the doses were compared for each radionuclide. The results of this comparison for total dose are shown in Table 5. The only radionuclide with a difference greater than $1 \%$ is I-135. The reason for this difference is two-fold: the short half-life of I135 ( $6.6 \mathrm{hrs})$ and the rounding of conversion factors and constants for time in MAXDOSESR and not in MAXINE. All other radionuclides are in good agreement.

Additional verification testing was performed by comparisons with MAXDOSE-SR test cases. All test cases for single release locations were compared and these results are shown in Table 6. Multiple release locations cannot be handled by MAXINE and therefore not all test cases are shown. As shown in Table 6 MAXDOSE-SR and MAXINE are in good agreement.

For quality assurance purposes, a detailed set of test cases was developed specifically for MAXINE. The input for these tests are shown in their entirety in Appendix A. These results should be used as a benchmark any time changes are made to MAXINE.

Hand calculations were performed for Cs-137 doses estimated from test case 1. Results of the hand calculations are shown in Table 7 for all pathways. The actual hand calculations are shown in Appendix B. Hand calculations produced identical results to the MAXINE spreadsheet results. 
Table 4. Input Parameters for Expanded Test Case

\begin{tabular}{|c|c|c|}
\hline Input Parameter & Value & Units \\
\hline Relative Concentration (X/Q): & $3.3 \mathrm{E}-08$ & $\mathrm{sec} / \mathrm{m}^{3}$ \\
\hline Decayed X/Q: & $3.2 \mathrm{E}-08$ & $\mathrm{sec} / \mathrm{m}^{3}$ \\
\hline Depleted X/Q: & 2.2E-08 & $\mathrm{sec} / \mathrm{m}^{3}$ \\
\hline Relative Deposition (D/Q): & $1.3 \mathrm{E}-10$ & $1 / \mathrm{m}^{2}$ \\
\hline Distance to Receptor: & 14014 & $\mathrm{~m}$ \\
\hline Vegetable Consumption (AVG, MAX, value): & $\max$ & $276 \mathrm{~kg} / \mathrm{yr}$ \\
\hline Leafy Veg Consumption (AVG, MAX, value): & $\max$ & $43 \mathrm{~kg} / \mathrm{yr}$ \\
\hline Milk Consumption (AVG, MAX, value): & $\max$ & $230 \mathrm{~L} / \mathrm{yr}$ \\
\hline Meat Consumption (AVG, MAX, value): & $\max$ & $81 \mathrm{~kg} / \mathrm{yr}$ \\
\hline Origin of Milk (Cow or Goat): & cow & \\
\hline Deposition Buildup Time(1/2 plant life): & 25 & $\mathrm{yr}$ \\
\hline Breathing Rate: & 8,000 & $\mathrm{~m}^{3} / \mathrm{yr}$ \\
\hline Elemental Iodine Fraction: & 0.50 & \\
\hline Absolute Humidity: & 0.01125 & $\mathrm{~kg} / \mathrm{m}^{3}$ \\
\hline Tritium Plant-to-Air Ratio: & 0.50 & \\
\hline Shielding Factor: & 0.70 & \\
\hline Fraction of Year C-14 Released: & 1.00 & \\
\hline Retained Fraction (iodines): & 1.00 & \\
\hline Retained Fraction (particulates): & 0.20 & \\
\hline Weathering Rate Constant: & 18.1 & $1 / \mathrm{yr}$ \\
\hline Crop Exposure Time: & 0.192 & $\mathrm{yr}$ \\
\hline Pasture Grass Exposure Time: & 0.0822 & $\mathrm{yr}$ \\
\hline Pasture Grass Productivity: & 1.8 & $\mathrm{~kg} / \mathrm{m}^{2}$ \\
\hline Produce Productivity: & 0.7 & $\mathrm{~kg} / \mathrm{m}^{2}$ \\
\hline Surface Soil Density $(15 \mathrm{~cm})$ : & 240 & $\mathrm{~kg} / \mathrm{m}^{2}$ \\
\hline Pasture Grass Holdup Time: & 0.00000 & yr \\
\hline Stored Feed Holdup Time: & 0.24700 & $\mathrm{yr}$ \\
\hline Leafy Vegetable Holdup Time: & 0.00274 & $\mathrm{yr}$ \\
\hline Produce Holdup Time: & 0.16400 & $\mathrm{yr}$ \\
\hline Milk Cattle Feed Consumption (52): & 44 & $\mathrm{~kg} / \mathrm{d}$ \\
\hline Beef Cattle Feed Consumption: & 44 & $\mathrm{~kg} / \mathrm{d}$ \\
\hline Feed-Milk-Man Transport Time: & 0.00548 & $\mathrm{yr}$ \\
\hline Fraction of Year on Pasture (beef): & 1.00 & \\
\hline Fraction of Year on Pasture (milk): & 1.00 & \\
\hline Fraction Intake from Pasture (beef): & 0.75 & \\
\hline Fraction Intake from Pasture (milk): & 0.56 & \\
\hline Slaughter to Consumption Time: & 0.0164 & $\mathrm{yr}$ \\
\hline Fraction of Produce from Garden: & 0.76 & \\
\hline Fraction of Leafy Vegs from Garden: & 1.00 & \\
\hline
\end{tabular}


Table 4 cont. Input for Expanded Test Case (Source Term in Curies)

\begin{tabular}{|l|l|}
\hline $\mathrm{H}-3$ (oxide) & $1.00 \mathrm{E}+02$ \\
$\mathrm{C}-14$ & $2.00 \mathrm{E}+02$ \\
$\mathrm{Ar}-41$ & $3.00 \mathrm{E}+02$ \\
$\mathrm{Cr}-51$ & $5.00 \mathrm{E}+02$ \\
$\mathrm{Co}-60$ & $5.00 \mathrm{E}+02$ \\
$\mathrm{Zn}-65$ & $2.00 \mathrm{E}+00$ \\
$\mathrm{Se}-75$ & $4.00 \mathrm{E}+00$ \\
$\mathrm{Kr}-85$ & $6.00 \mathrm{E}+00$ \\
$\mathrm{Kr}-85 \mathrm{~m}$ & $8.00 \mathrm{E}+00$ \\
$\mathrm{Kr}-87$ & $1.00 \mathrm{E}+01$ \\
$\mathrm{Kr}-88$ & $1.00 \mathrm{E}+00$ \\
$\mathrm{Sr}-90$ & $3.00 \mathrm{E}+00$ \\
$\mathrm{Zr}-95 \dagger$ & $5.00 \mathrm{E}+00$ \\
$\mathrm{Nb}-95$ & $7.00 \mathrm{E}+00$ \\
$\mathrm{Ru}-103$ & $9.00 \mathrm{E}+00$ \\
$\mathrm{Ru}-106 \dagger$ & $1.00 \mathrm{E}+03$ \\
$\mathrm{Sb}-125$ & $5.00 \mathrm{E}+03$ \\
$\mathrm{I}-129$ & $1.00 \mathrm{E}+04$ \\
$\mathrm{I}-131$ & $1.00 \mathrm{E}-04$ \\
$\mathrm{I}-133$ & $2.00 \mathrm{E}-04$ \\
$\mathrm{I}-135$ & $3.00 \mathrm{E}-04$ \\
$\mathrm{Xe}-131 \mathrm{~m}$ & $4.00 \mathrm{E}-04$ \\
$\mathrm{Xe}-133$ & $5.00 \mathrm{E}-04$ \\
$\mathrm{Xe}-135$ & $6.00 \mathrm{E}-04$ \\
$\mathrm{Cs}-134$ & $7.00 \mathrm{E}-04$ \\
$\mathrm{Cs}-137$ & $8.00 \mathrm{E}-04$ \\
$\mathrm{Ce}-141$ & $9.00 \mathrm{E}-04$ \\
$\mathrm{Ce}-144$ & $1.00 \mathrm{E}-03$ \\
$\mathrm{Pm}-147$ & $1.23 \mathrm{E}-01$ \\
$\mathrm{Eu}-154$ & $4.56 \mathrm{E}-01$ \\
$\mathrm{Eu}-155$ & $7.89 \mathrm{E}-01$ \\
$\mathrm{Os}-185$ & $1.10 \mathrm{E}+00$ \\
$\mathrm{U}-234$ & $2.20 \mathrm{E}+00$ \\
$\mathrm{U}-235 \dagger$ & $3.30 \mathrm{E}+00$ \\
$\mathrm{U}-238$ & $4.40 \mathrm{E}+00$ \\
$\mathrm{~Np}-237$ & $5.50 \mathrm{E}+00$ \\
$\mathrm{Pu}-238$ & $6.60 \mathrm{E}+00$ \\
$\mathrm{Pu}-239$ & $7.70 \mathrm{E}+00$ \\
$\mathrm{Am}-241$ & $8.80 \mathrm{E}+00$ \\
$\mathrm{Am}-243$ & $9.90 \mathrm{E}+00$ \\
$\mathrm{Cm}-242$ & $1.10 \mathrm{E}+01$ \\
$\mathrm{Cm}-244$ & $2.20 \mathrm{E}+01$ \\
$\mathrm{Cf}-252$ & $3.30 \mathrm{E}+01$ \\
\hline &
\end{tabular}


Table 5. Results of Detailed Test Case

\begin{tabular}{|c|c|c|c|}
\hline & $\begin{array}{c}\text { MAXDOSE-SR } \\
\text { Dose (mrem) }\end{array}$ & $\begin{array}{c}\text { MAXINE } \\
\text { Dose (mrem) }\end{array}$ & \% Difference \\
\hline AR 41 & $5.27 \mathrm{E}-04$ & $5.27 \mathrm{E}-04$ & 0.0 \\
\hline AM241 & $4.69 \mathrm{E}+01$ & $4.69 \mathrm{E}+01$ & 0.0 \\
\hline AM243 & $5.28 \mathrm{E}+01$ & $5.28 \mathrm{E}+01$ & 0.0 \\
\hline C 14 & $1.47 \mathrm{E}-01$ & $1.46 \mathrm{E}-01$ & -0.7 \\
\hline CE141 & $4.90 \mathrm{E}-07$ & 4.91E-07 & 0.2 \\
\hline CE144 & $1.15 \mathrm{E}-05$ & $1.15 \mathrm{E}-05$ & 0.0 \\
\hline CF252 & $4.00 \mathrm{E}+01$ & $4.00 \mathrm{E}+01$ & 0.0 \\
\hline CM242 & $1.55 \mathrm{E}+00$ & $1.55 \mathrm{E}+00$ & 0.0 \\
\hline CM244 & $6.04 \mathrm{E}+01$ & $6.04 \mathrm{E}+01$ & 0.0 \\
\hline CO 60 & $8.54 \mathrm{E}+01$ & $8.53 \mathrm{E}+01$ & -0.1 \\
\hline CR 51 & 2.69E-02 & $2.69 \mathrm{E}-02$ & 0.0 \\
\hline CS134 & $6.42 \mathrm{E}-05$ & $6.43 \mathrm{E}-05$ & 0.2 \\
\hline CS137 & $1.11 \mathrm{E}-04$ & $1.11 \mathrm{E}-04$ & 0.0 \\
\hline EU154 & $5.83 \mathrm{E}-02$ & $5.84 \mathrm{E}-02$ & 0.2 \\
\hline EU155 & 4.37E-03 & 4.36E-03 & -0.2 \\
\hline $\begin{array}{ll}H & 3\end{array}$ & $1.66 \mathrm{E}-04$ & $1.66 \mathrm{E}-04$ & 0.0 \\
\hline I 129 & $4.39 \mathrm{E}+03$ & $4.39 \mathrm{E}+03$ & 0.0 \\
\hline I 131 & $5.68 \mathrm{E}-07$ & $5.68 \mathrm{E}-07$ & 0.0 \\
\hline I 133 & $2.13 \mathrm{E}-08$ & $2.11 \mathrm{E}-08$ & -0.9 \\
\hline I 135 & $3.59 \mathrm{E}-09$ & $3.54 \mathrm{E}-09$ & -1.4 \\
\hline KR 85 & 4.91E-08 & 4.91E-08 & 0.0 \\
\hline KR 85M & $3.15 \mathrm{E}-06$ & $3.15 \mathrm{E}-06$ & 0.0 \\
\hline KR 87 & 7.60E-06 & 7.60E-06 & 0.0 \\
\hline KR 88 & $5.66 \mathrm{E}-06$ & $5.65 \mathrm{E}-06$ & -0.2 \\
\hline NB 95 & $1.59 \mathrm{E}-02$ & $1.59 \mathrm{E}-02$ & 0.0 \\
\hline NP237 & $2.68 \mathrm{E}+01$ & $2.68 \mathrm{E}+01$ & 0.0 \\
\hline OS185 & $5.79 \mathrm{E}-03$ & $5.80 \mathrm{E}-03$ & 0.2 \\
\hline PM147 & $8.36 \mathrm{E}-05$ & $8.36 \mathrm{E}-05$ & 0.0 \\
\hline PU238 & $3.04 \mathrm{E}+01$ & $3.04 \mathrm{E}+01$ & 0.0 \\
\hline PU239 & $3.97 \mathrm{E}+01$ & $3.97 \mathrm{E}+01$ & 0.0 \\
\hline RU103 & $2.62 \mathrm{E}-02$ & $2.62 \mathrm{E}-02$ & 0.0 \\
\hline RU106 & $4.25 \mathrm{E}+01$ & $4.25 \mathrm{E}+01$ & 0.0 \\
\hline SB125 & $9.05 \mathrm{E}+01$ & $8.98 \mathrm{E}+01$ & -0.8 \\
\hline SE 75 & 4.18E-02 & 4.18E-02 & 0.0 \\
\hline SR 90 & $2.46 \mathrm{E}-01$ & $2.46 \mathrm{E}-01$ & 0.0 \\
\hline U 234 & $1.95 \mathrm{E}+00$ & $1.95 \mathrm{E}+00$ & 0.0 \\
\hline U 235 & $2.85 \mathrm{E}+00$ & $2.85 \mathrm{E}+00$ & 0.0 \\
\hline U 238 & $3.57 \mathrm{E}+00$ & $3.57 \mathrm{E}+00$ & 0.0 \\
\hline XE131M & $1.25 \mathrm{E}-11$ & $1.25 \mathrm{E}-11$ & 0.0 \\
\hline XE133 & $6.34 \mathrm{E}-11$ & $6.34 \mathrm{E}-11$ & 0.0 \\
\hline XE135 & $4.47 \mathrm{E}-10$ & $4.47 \mathrm{E}-10$ & 0.0 \\
\hline ZN 65 & $3.95 \mathrm{E}-02$ & $3.95 \mathrm{E}-02$ & 0.0 \\
\hline ZR 95 & $2.46 \mathrm{E}-02$ & $2.46 \mathrm{E}-02$ & 0.0 \\
\hline
\end{tabular}


Table 6. Comparison of MAXDOSE-SR Test Cases with MAXINE

\begin{tabular}{|c|c|c|c|}
\hline Test Case & $\begin{array}{c}\text { MAXDOSE-SR } \\
\text { Dose (mrem) }\end{array}$ & $\begin{array}{c}\text { MAXINE } \\
\text { Dose (mrem) }\end{array}$ & \% Difference \\
\hline $\mathbf{1}$ & $3.21 \mathrm{E}+01$ & $3.22 \mathrm{E}+01$ & -0.3 \\
$\mathbf{2}$ & $3.23 \mathrm{E}+00$ & $3.23 \mathrm{E}+00$ & 0.0 \\
$\mathbf{3}$ & $2.17 \mathrm{E}+00$ & $2.17 \mathrm{E}+00$ & 0.0 \\
$\mathbf{4}$ & $8.00 \mathrm{E}-01$ & $8.00 \mathrm{E}-01$ & 0.0 \\
$\mathbf{9}$ & $5.09 \mathrm{E}+00$ & $5.11 \mathrm{E}+00$ & -0.4 \\
\hline
\end{tabular}

Table 7. Comparison of MAXINE with Hand Calculations

\begin{tabular}{|l|c|c|c|}
\hline Pathway & $\begin{array}{l}\text { MAXINE } \\
\text { Dose (mrem) }\end{array}$ & $\begin{array}{l}\text { Hand Calculated } \\
\text { Dose (mrem) }\end{array}$ & \% Difference \\
\hline Shine & $2.1 \mathrm{E}-01$ & $2.1 \mathrm{E}-01$ & 0.00 \\
Inhalation & $2.0 \mathrm{E}-04$ & $2.0 \mathrm{E}-04$ & 0.00 \\
Vegetables & $4.1 \mathrm{E}-02$ & $4.1 \mathrm{E}-02$ & 0.00 \\
Milk & $3.8 \mathrm{E}-02$ & $3.8 \mathrm{E}-02$ & 0.00 \\
Meat & $9.8 \mathrm{E}-04$ & $9.8 \mathrm{E}-04$ & 0.00 \\
Total & $2.9 \mathrm{E}-01$ & $2.9 \mathrm{E}-01$ & 0.00 \\
\hline
\end{tabular}

\section{USER'S MANUAL}

\subsection{First Time User Instructions}

The programming for MAXINE is contained in one EXCEL@ File entitled 'MAXINE.XLS'. Simply copying this file to your computer installs the program. The spreadsheet has been locked to avoid inadvertent changes to cells performing calculations. Following installation, it is recommended that the user execute at least one test case to ensure the spreadsheet is operating correctly.

\subsection{Input Instructions}

Table 4 shows the input template in its entirety. In viewing the actual spreadsheet, the user has the ability to change all parameters shown in red. All other cells have been locked to prevent user access. The spreadsheet is set up such that default values are included for each parameter except the source term. Each parameter is discussed in detail below. 

Relative Concentration (X/Q): $\quad$ Enter the relative air concentration in units of $\mathrm{s} / \mathrm{m}^{3}$ for the location of interest. This input is likely estimated using the methods detailed in U.S. NRC Regulatory Guide 1.111 (USNRC 1977b). Valid Range $1 \mathrm{E}-10$ to $1 \mathrm{E}-05 \mathrm{~s} / \mathrm{m}^{3}$.
Decayed X/Q: $\quad$ Enter the 2.26 day decayed relative air concentration in units of $\mathrm{s} / \mathrm{m}^{3}$ for the location of interest. Valid Range $1 \mathrm{E}-10$ to $1 \mathrm{E}-05 \mathrm{~s} / \mathrm{m}^{3}$.
Depleted X/Q: $\quad$ Enter the 8-day decayed and depleted relative air concentration in units of $\mathrm{s} / \mathrm{m}^{3}$ for the location of interest. Valid Range $1 \mathrm{E}-10$ to $1 \mathrm{E}-05 \mathrm{~s} / \mathrm{m}^{3}$.
Relative Deposition (D/Q):
Distance to Receptor: Enter the distance from the release point to the downwind location of the receptor in meters. Valid Range: 0 to $80,000 \mathrm{~m}$
Vegetable Consumption: Enter the vegetable consumption rate for the exposed individual as AVG, MAX or a value. The average consumption rate is $163 \mathrm{~kg} / \mathrm{yr}$ and the max consumption rate is $276 \mathrm{~kg} / \mathrm{yr}$. Valid Range: 0 to $900 \mathrm{~kg} / \mathrm{yr}$

Leafy Veg Consumption : $\quad$ Enter the leafy vegetable consumption rate for the exposed individual as AVG, MAX or a value. The average consumption rate is $21 \mathrm{~kg} / \mathrm{yr}$ and the max consumption rate is $43 \mathrm{~kg} / \mathrm{yr}$. Valid Range 0 to $260 \mathrm{~kg} / \mathrm{yr}$

Milk Consumption : $\quad$ Enter the milk consumption rate for the exposed individual as AVG, MAX or a value. The average consumption rate is $120 \mathrm{Lyr}$ and the max consumption rate is $230 \mathrm{~L} / \mathrm{yr}$. Valid Range 0 to $500 \mathrm{~L} / \mathrm{yr}$

Meat Consumption: Enter the meat consumption rate for the exposed individual as AVG, MAX or a value. The average consumption rate is $43 \mathrm{~kg} / \mathrm{yr}$ and the max consumption rate is $81 \mathrm{~kg} / \mathrm{yr}$. Valid Range 0 to $470 \mathrm{~kg} / \mathrm{yr}$ 
Origin of Milk: $\quad$ Enter the type of milk consumed by the exposed individual either as COW or GOAT.

Deposition Buildup Time: Enter the time (in years) that the radionuclides have been accumulating in the soil. Valid Range: $0-100 \mathrm{yr}$

Breathing Rate: Enter the inhalation rate of the individual in $\mathrm{m}^{3} / \mathrm{yr}$. Valid range is 6000 to $10000 \mathrm{~m}^{3} / \mathrm{yr}$

Elemental Iodine Fraction: Enter the fraction of iodine released that is elemental. The balance is assumed to behave as a gas. Valid Range: 0-1

Absolute Humidity: Enter the annual average absolute humidity in $\mathrm{kg} / \mathrm{m}^{3}$. Valid Range: 0.003 to $0.020 \mathrm{~kg} / \mathrm{m}^{3}$

Tritium Plant-to-Air Ratio: Enter the ratio of tritium concentration in the plant moisture to tritium concentration in atmospheric moisture. Valid Range: 0-5

Shielding Factor: $\quad$ Enter the fraction of time that the individual is exposed to gamma radiation. Valid Rage: 0-1

Fraction of Year C-14 Released: Enter the ratio of the total annual release time to the total annual time during which photsynthesis occurs (taken to be $4400 \mathrm{hrs}$ ). For continual releases a value of one should be entered. Valid Range: 0-1

Retained Fraction (iodines): $\quad$ Enter the fraction of elemental iodine that is retained on the surface of the vegetation following deposition. Valid Range: 0-1

Retained Fraction (particulates): $\quad$ Enter the fraction of particulates that are retained on the surface of the vegetation. Valid Range: 0-1

Weathering Rate Constant: Enter the rate constant describing the removal of particulates from plant surfaces due to weathering. Valid Range: 5 - 250 1/yr

Crop Exposure Time: $\quad$ Enter the length of time (in yrs) the crops are exposed. This typically equates to the growing season. Valid Range: 0-1 yr

Pasture Grass Exposure Time: Enter the length of time (in yrs) pasture grass is exposed. Valid Range: 0-1 yr 
Pasture Grass Productivity: $\quad$ Enter the productivity of pasture grass in $\mathrm{kg} / \mathrm{m}^{2}$.

Valid Range: $0-3 \mathrm{~kg} / \mathrm{m}^{2}$

Produce Productivity: Enter the productivity of produce in $\mathrm{kg} / \mathrm{m}^{2}$. Valid Range: $0-3 \mathrm{~kg} / \mathrm{m}^{2}$

Surface Soil Density: $\quad$ Enter the surface soil density in units of $\mathrm{kg} / \mathrm{m}^{2}$ assuming a contamination depth of $15 \mathrm{~cm}$. Valid Range: $50-400 \mathrm{~kg} / \mathrm{m}^{2}$.

Pasture Grass Holdup Time: $\quad$ Enter the length of time (in yrs) between contamination and consumption of pasture grass by grazing cows or goats. Valid Range: $0-1 \mathrm{yr}$

Stored Feed Holdup Time: $\quad$ Enter the length of time (in yrs) feed is stored prior to consumption by livestock. Valid Range: 0 $-1 \mathrm{yr}$

Leafy Vegetable Holdup Time: $\quad$ Enter the length of time (in yrs) leafy vegetables are stored prior to consumption. Valid Range: $0-$ $1 \mathrm{yr}$

Produce Holdup Time: $\quad$ Enter the length of time (in yrs) vegetables are stored prior to consumption. Valid Range: $0-1$ yr

Milk Cattle (Goat) Feed

Enter the fodder consumption rate for milk cattle Consumption: or goats in $\mathrm{kg} / \mathrm{d}$. Depending on what is input above under origin of milk, the input statement will change to reflect either milk cattle or goats. The expected value for milk cows is $52 \mathrm{~kg} / \mathrm{d}$ and the expected value for goats is $6 \mathrm{~kg} / \mathrm{d}$. Valid Range: $0-100 \mathrm{~kg} / \mathrm{d}$

Beef Cattle Feed Consumption: Enter the fodder consumption rate for beef cattle in $\mathrm{kg} / \mathrm{d}$. Valid Range: $0-100 \mathrm{~kg} / \mathrm{d}$

Feed-Milk-Man Transport Time: $\quad$ Enter the length of time (in yrs) from milking to consumption by exposed individual. Valid Range: $0-0.038$ yr

Fraction of Year on Pasture (beef): $\quad$ Enter the fraction of the year that beef cattle are on the pasture. Valid Range 0-1

Fraction of Year on Pasture (milk): $\quad$ Enter the fraction of the year that milk cattle or goats are on the pasture. Valid Range 0-1 
Fraction Intake from Pasture (beef): $\quad$ Enter the fraction of a beef cow's diet that is pasture grass while the cow is on pasture. Valid Range: 0-1

Fraction Intake from Pasture (milk): Enter the fraction of a milk cow's or goat's diet that is pasture grass while on pasture. Valid Range: 0-1

Slaughter to Consumption Time: Enter the length of time (in yrs) between cattle slaughter and consumption by humans. Valid Range: 0-0.38 yr.

Fraction of Produce from Garden: Enter the fraction of produce consumed that was grown in local garden. The remaining produce is assumed not to be contaminated. Valid Range: 01.

Fraction of Leafy Vegetables from Enter the fraction of leafy vegetables consumed Garden: that were grown in local garden. The remaining leafy vegetables are assumed not to be contaminated. Valid Range: 0-1

\subsection{Output Files Generated}

Appendix $\mathrm{C}$ shows the MAXINE spreadsheet in its entirety for test case 1. Pages 1 and 2 show user-input. Pages 3 and 4 show radionuclide specific constants used in the dose estimates. The last two pages show the concentration and dose by radionuclide and pathway.

\section{CONCLUSIONS}

MAXINE is performing as expected and producing correct results for a wide range of test cases. Minimal input is required by the user and output is available in an easily interpreted form. Recommended improvements to MAXINE would be to add atmospheric dispersion estimates to the spreadsheet or link to another spreadsheet that would perform this function. 


\section{REFERENCES}

Bauer, L.R. and Hamby, D.M., "Relative Sensitivities of Existing and Novel Model Parameters in Atmospheric Tritium Dose Estimates," Radiation Protection Dosimetry, Volume 37, No. 4, pp. 253-260, 1991.

Eckerman, K.F., Congel, F.J., Roecklien, A.K., and Pasciak, W.J., "User's Guide to GASPAR Code,” NUREG/-0597, U.S. Nuclear Regulatory Commission, Washington, DC, June 1980.

Hamby, D.M., “Average Absolute Humidity at the Savannah River Site,” Westinghouse Savannah River Company Inter-Office Memorandum: SRL-ETS-900141, Aiken, SC, March 22, 1990.

Hamby, D.M., "Land and Water-Use Characteristics in the Vicinity of the Savannah River Site,” WSRC-RP-91-17, Westinghouse Savannah River Company, Aiken, SC, March 1991.

Hamby, D.M., “A Probabilistic Estimation of Atmospheric Tritium Dose," Health Physics, 65: 33-40, 1993.

Hamby, D.M., and Bauer, L.R., 'The vegetation-to-air concentration ratio in a specific activity atmospheric tritium model', Health Physics, 66:339-342, 1994.

Simpkins, A.A. "MAXDOSE-SR: A Routine-Release Atmospheric Dose Model used at SRS.” Westinghouse Savannah River Company Report: WSRC-TR-99-00281, Aiken, SC 1999.

U.S. Department of Energy, External Dose-Rate Conversion Factors for Calculation of Dose to the Public, DOE/EH-0070, Washington, DC 1988a.

U.S. Department of Energy, Internal Dose Conversion Factors for Calculation of Dose to the Public, DOE/EH-0071, Washington, DC, 1988 b.

U.S. Nuclear Regulatory Commission, "Calculation of Annual Dose to Man from Routine Releases of Reactor Effluents for the Purpose of Evaluating Compliance with 10CFR50 Appendix I,” Regulatory Guide 1.109, Rev 1, Washington, DC, October 1977a.

U.S. Nuclear Regulatory Commission, "Methods for Estimating Atmospheric Transport and Dispersion of Gaseous Effluents in Routine Releases from Light-Water-Cooled Reactors," Regulatory Guide 1.111, Rev. 1, Washington, DC, July 1977b. 


\section{APPENDIX A. MAXINE TEST CASES}




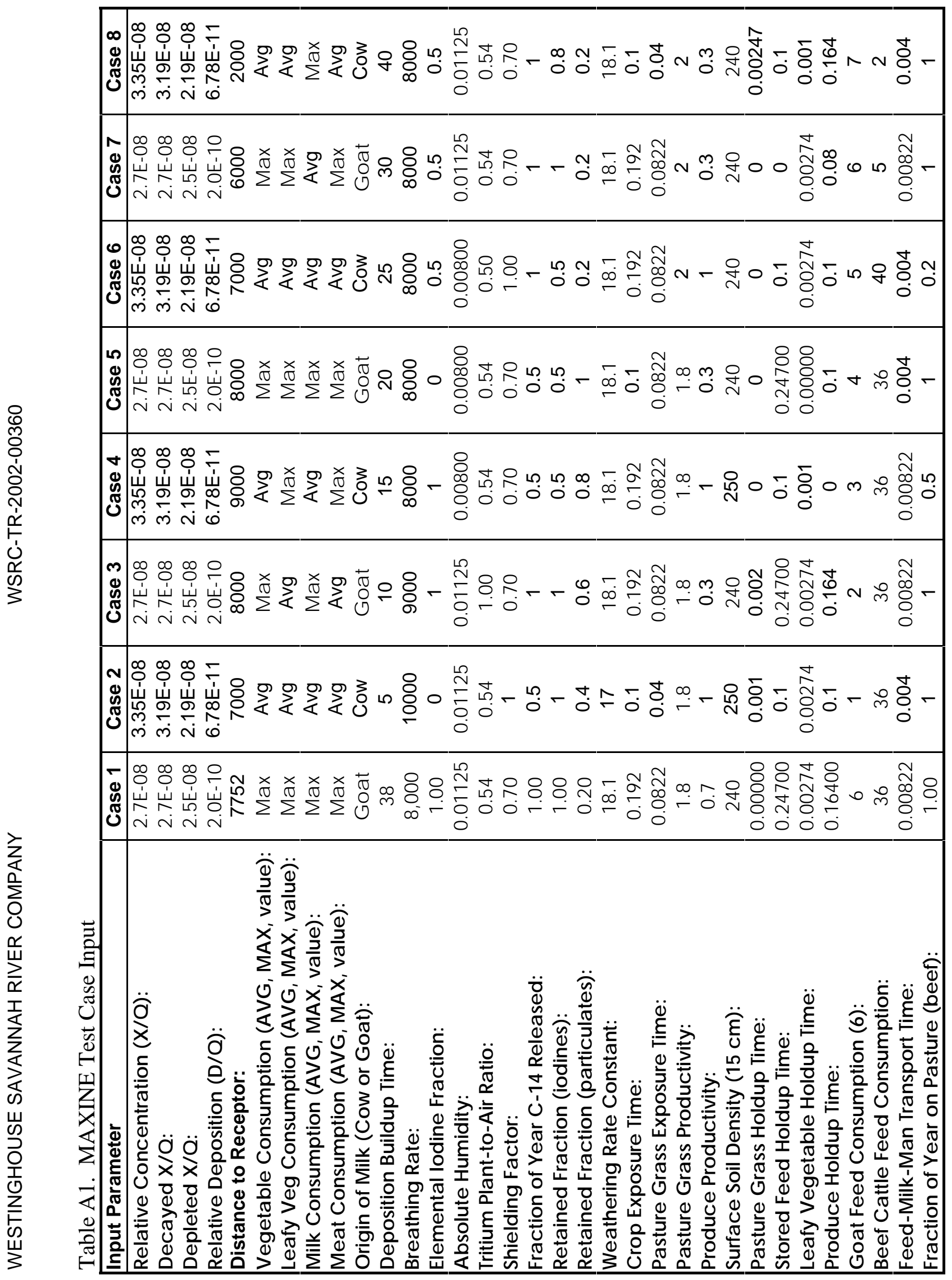




\begin{tabular}{|c|c|}
\hline$\left|\begin{array}{c}\sim \\
\vdots \\
0\end{array}\right|$ & 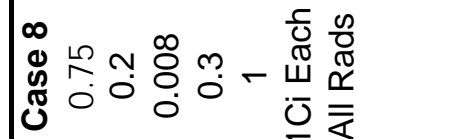 \\
\hline סִ & 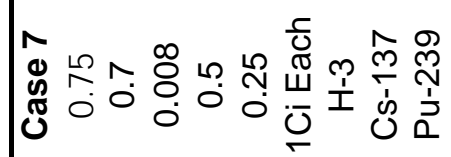 \\
\hline$\left|\begin{array}{l}2 \\
0 \\
0\end{array}\right|$ & 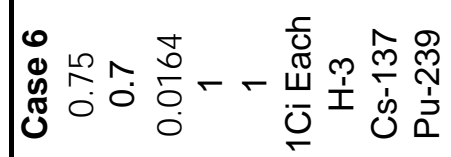 \\
\hline I- & 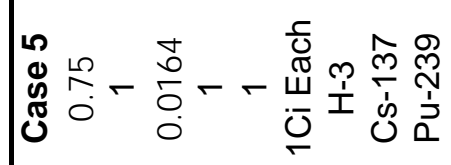 \\
\hline- & 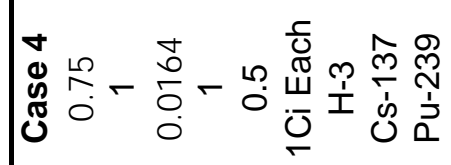 \\
\hline- & 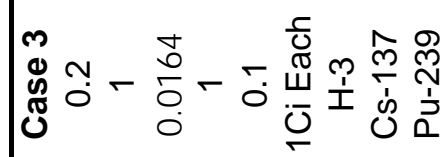 \\
\hline I- & 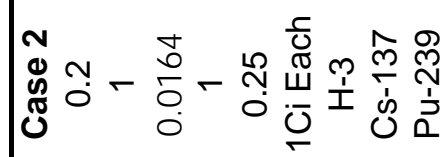 \\
\hline $\mid \begin{array}{ll}2 \\
2 \\
0 \\
0\end{array}$ & 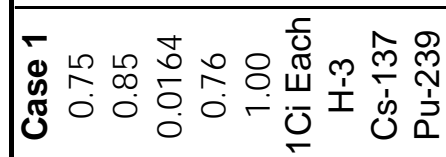 \\
\hline 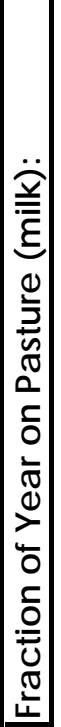 & 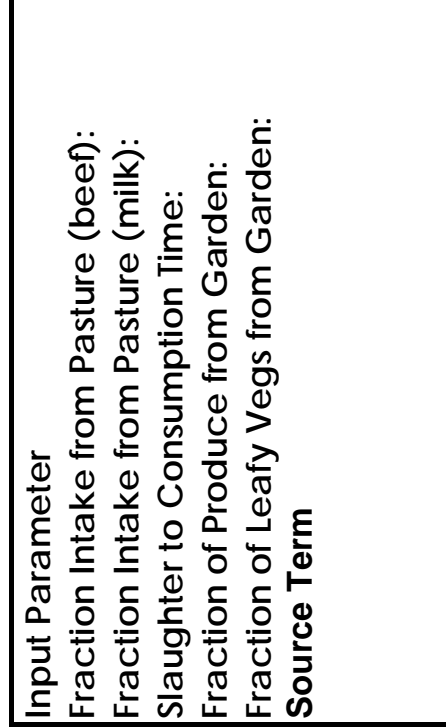 \\
\hline
\end{tabular}


WESTINGHOUSE SAVANNAH RIVER COMPANY

\section{APPENDIX B. HAND CALCULATIONS}


The following shows hand calculations for MAXINE Test Case 1 (shown in Table A1) for Cs-137. Appendix C shows the corresponding MAXINE output in its entirety.

\section{Inhalation Dose}

$$
\begin{aligned}
& \mathrm{t}=\frac{\ln \left(\frac{\chi_{\mathrm{D}} / \mathrm{Q}}{\chi / \mathrm{Q}}\right)}{\left(\frac{\ln 2 \cdot 365 \mathrm{~d}}{2.26 \mathrm{~d} \cdot 1 \mathrm{yr}}\right)} \\
& \mathrm{t}=\frac{\ln \left(\frac{2.7 \mathrm{E}-08 \frac{\mathrm{s}}{\mathrm{m}^{3}}}{2.7 \mathrm{E}-08 \frac{\mathrm{s}}{\mathrm{m}^{3}}}\right)}{\left(\frac{\ln 2 \bullet 365 \mathrm{~d}}{2.26 \mathrm{~d} \bullet 1 \mathrm{yr}}\right)} \\
& \mathrm{t}=0 \mathrm{yr} \\
& \chi_{\mathrm{i}}=\frac{\chi_{\mathrm{DD}}}{\mathrm{Q}} \bullet \mathrm{Q}_{\mathrm{i}} \cdot 10^{6} \bullet 3.17 \times 10^{-8} \frac{\mathrm{yr}}{\mathrm{s}} \bullet \mathrm{e}^{\left(31.62-\lambda_{\mathrm{t}}\right) \mathrm{t}} \\
& \chi_{\mathrm{i}}=2.5 \mathrm{E}-08 \frac{\mathrm{s}}{\mathrm{m}^{3}} \bullet 1 \frac{\mathrm{Ci}}{\mathrm{yr}} \bullet 10^{6} \frac{\mu \mathrm{Ci}}{\mathrm{Ci}} \bullet 3.17 \times 10^{-8} \frac{\mathrm{yr}}{\mathrm{s}} \bullet \mathrm{e}^{(31.62-0.023) 0} \\
& \chi_{\mathrm{i}}=7.925 \mathrm{E}-10 \frac{\mu \mathrm{Ci}}{\mathrm{m}^{3}} \\
& \mathrm{D}_{\mathrm{h}}^{\mathrm{inh}}=\chi_{\mathrm{i}} \bullet \mathrm{BR} \bullet \mathrm{DF}_{\mathrm{i}}^{\mathrm{inh}} \bullet 1000\left[\frac{\mathrm{mrem}}{\mathrm{rem}}\right] \bullet 1 \mathrm{yr} \\
& \mathrm{D}_{\mathrm{h}}^{\mathrm{inh}}=7.925 \mathrm{E}-10 \frac{\mu \mathrm{Ci}}{\mathrm{m}^{3}} \bullet 8000 \frac{\mathrm{m}^{3}}{\mathrm{yr}} \bullet 3.2 \mathrm{E}-2 \frac{\mathrm{rem}}{\mu \mathrm{Ci}} \bullet 1000\left[\frac{\mathrm{mrem}}{\mathrm{rem}}\right] \bullet 1 \mathrm{yr} \\
& \mathrm{D}_{\mathrm{h}}^{\mathrm{inh}}=2.0 \mathrm{E}-04 \mathrm{mrem}
\end{aligned}
$$




\section{Ground Shine Dose}

$\mathrm{d}_{\mathrm{i}}=\frac{\mathrm{D}}{\mathrm{Q}} \bullet \mathrm{Q}_{\mathrm{i}} \cdot 10^{6} \bullet \mathrm{e}^{\left(31.62-\lambda_{\mathrm{i}}\right) \mathrm{t}}$

$\mathrm{d}_{\mathrm{i}}=2.0 \mathrm{E}-10 \frac{1}{\mathrm{~m}^{2}} \cdot 1 \frac{\mathrm{Ci}}{\mathrm{yr}} \bullet 10^{6} \bullet \mathrm{e}^{(31.62-0.023) 0}$

$\mathrm{d}_{\mathrm{i}}=2.0 \mathrm{E}-04 \frac{\mu \mathrm{Ci}}{\mathrm{m}^{2} \mathrm{yr}}$

$\mathrm{D}_{\mathrm{i}}^{\mathrm{g}}=\mathrm{d}_{\mathrm{i}} \bullet \mathrm{SF} \bullet \mathrm{DF}_{\mathrm{i}}^{\mathrm{g}} \bullet \frac{1-\mathrm{e}^{-\lambda_{\mathrm{i}} \mathrm{t}_{\mathrm{b}}}}{\lambda_{\mathrm{i}}} \bullet 1 \mathrm{yr}$

$\mathrm{D}_{\mathrm{i}}^{\mathrm{g}}=2.0 \mathrm{E}-04 \frac{\mu \mathrm{Ci}}{\mathrm{m}^{2} \mathrm{yr}} \bullet 0.7 \bullet 57.8 \frac{\mathrm{mrem} \bullet \mathrm{m}^{2}}{\mu \mathrm{Ci} \bullet \mathrm{yr}} \bullet \frac{1-\mathrm{e}^{-0.023 * 38}}{0.023 \mathrm{yr}^{-1}} \bullet 1 \mathrm{yr}$

$\mathrm{D}_{\mathrm{i}}^{\mathrm{g}}=2.1 \mathrm{E}-01 \mathrm{mrem}$

\section{Vegetable Ingestion Dose}

$$
\begin{aligned}
& \mathrm{C}_{\mathrm{i}}^{\mathrm{V}}=\mathrm{d}_{\mathrm{i}} \bullet\left[\frac{\mathrm{r}_{\mathrm{i}}\left(1-\mathrm{e}^{-\lambda_{\mathrm{i}}^{\mathrm{w}} \mathrm{t}_{\mathrm{e}}}\right)}{\mathrm{Y}_{\mathrm{v}} \lambda_{\mathrm{i}}^{\mathrm{w}}}+\frac{\mathrm{B}_{\mathrm{i}}^{\mathrm{v}}\left(1-\mathrm{e}^{-\lambda_{\mathrm{i}} \mathrm{t}_{\mathrm{b}}}\right)}{\mathrm{P} \bullet \lambda_{\mathrm{i}}}\right] \bullet \mathrm{e}^{-\lambda_{\mathrm{i}} \mathrm{t}_{\mathrm{h}}} \\
& \mathrm{C}_{\mathrm{i}}^{\mathrm{V}}=2.0 \mathrm{E}-04 \frac{\mu \mathrm{Ci}}{\mathrm{m}^{2} \mathrm{yr}} \bullet\left[\frac{0.2\left(1-\mathrm{e}^{-(18.1+0.023) 0.192}\right)}{0.7 \frac{\mathrm{kg}}{\mathrm{m}^{2}}(18.1+0.023) \mathrm{yr}^{-1}}+\frac{1 \mathrm{E}-2\left(1-\mathrm{e}^{-0.023^{*} 38}\right)}{240 \frac{\mathrm{kg}^{2}}{\mathrm{~m}^{2}} 0.023 \mathrm{yr}^{-1}}\right] \bullet \mathrm{e}^{-0.023^{*} 0.164} \\
& \mathrm{C}_{\mathrm{i}}^{\mathrm{V}}=3.3 \mathrm{E}-06 \frac{\mu \mathrm{Ci}}{\mathrm{kg}} \\
& \mathrm{C}_{\mathrm{i}}^{\mathrm{LV}}=2.0 \mathrm{E}-04 \frac{\mu \mathrm{Ci}}{\mathrm{m}^{2} \mathrm{yr}} \bullet\left[\frac{0.2\left(1-\mathrm{e}^{-(18.1+0.023) 0.192}\right)}{0.7 \frac{\mathrm{kg}}{\mathrm{m}^{2}}(18.1+0.023) \mathrm{yr}^{-1}}+\frac{1 \mathrm{E}-2\left(1-\mathrm{e}^{-0.023^{*} 38}\right)}{240 \frac{\mathrm{kg}^{2}}{\mathrm{~m}^{2}} 0.023 \mathrm{yr}^{-1}}\right] \bullet \mathrm{e}^{-0.023^{*} 0.00274} \\
& \mathrm{C}_{\mathrm{i}}^{\mathrm{LV}}=3.3 \mathrm{E}-06 \frac{\mu \mathrm{Ci}}{\mathrm{kg}} \\
& \mathrm{D}_{\mathrm{i}}^{\mathrm{veg}}=\left[\mathrm{C}_{\mathrm{i}}^{\mathrm{v}} \mathrm{U}^{\mathrm{v}} \mathrm{f}_{\mathrm{v}}+\mathrm{C}_{\mathrm{i}}^{\mathrm{l}} \mathrm{U}^{\mathrm{l}} \mathrm{f}_{1}\right] \bullet \mathrm{DF} \mathrm{F}_{\mathrm{i}}^{\mathrm{ing}} \bullet 1000 \frac{\mathrm{mrem}}{\mathrm{rem}} \bullet 1 \mathrm{yr} \\
& \mathrm{D}_{\mathrm{i}}^{\mathrm{veg}}=\left[3.3 \mathrm{E}-6 \frac{\mu \mathrm{Ci}}{\mathrm{kg}} 276 \frac{\mathrm{kg}}{\mathrm{yr}} 0.76+3.3 \mathrm{E}-6 \frac{\mu \mathrm{Ci}}{\mathrm{kg}} 43 \frac{\mathrm{kg}}{\mathrm{yr}} 1.0\right] \bullet 5.0 \mathrm{E}-02 \frac{\mathrm{rem}}{\mu \mathrm{Ci}} \bullet 1000 \frac{\mathrm{mrem}}{\mathrm{rem}} \bullet 1 \mathrm{yr} \\
& \mathrm{D}_{\mathrm{i}}^{\mathrm{veg}}=0.041 \mathrm{mrem}
\end{aligned}
$$




\section{$\underline{\text { Milk Ingestion Dose }}$}

$$
\begin{aligned}
& \mathrm{C}_{\mathrm{i}}^{\mathrm{P}}=\mathrm{d}_{\mathrm{i}} \bullet\left[\frac{\mathrm{r}_{\mathrm{i}}\left(1-\mathrm{e}^{-\lambda_{\mathrm{i}}^{\mathrm{w}} \mathrm{t}_{\mathrm{e}}}\right)}{\mathrm{Y}_{\mathrm{V}} \lambda_{\mathrm{i}}^{\mathrm{w}}}+\frac{\mathrm{B}_{\mathrm{i}}^{\mathrm{v}}\left(1-\mathrm{e}^{-\lambda_{\mathrm{i}} \mathrm{t}_{\mathrm{b}}}\right)}{\mathrm{P} \bullet \lambda_{\mathrm{i}}}\right] \bullet \mathrm{e}^{-\lambda_{\mathrm{i}} \mathrm{t}_{\mathrm{h}}} \\
& \mathrm{C}_{\mathrm{i}}^{\mathrm{P}}=2.0 \mathrm{E}-04 \frac{\mu \mathrm{Ci}}{\mathrm{m}^{2} \mathrm{yr}} \bullet\left[\frac{0.2\left(1-\mathrm{e}^{-(18.1+0.023) 0.0822}\right)}{1.8 \frac{\mathrm{kg}}{\mathrm{m}^{2}}(18.1+0.023) \mathrm{yr}^{-1}}+\frac{1 \mathrm{E}-2\left(1-\mathrm{e}^{-0.023^{*} 38}\right)}{240 \frac{\mathrm{kg}}{\mathrm{m}^{2}} 0.023 \mathrm{yr}^{-1}}\right] \bullet \mathrm{e}^{-0.023^{*} 0} \\
& \mathrm{C}_{\mathrm{i}}^{\mathrm{P}}=1.16 \mathrm{E}-06 \frac{\mu \mathrm{Ci}}{\mathrm{kg}} \\
& C_{i}^{S}=d_{i} \bullet\left[\frac{r_{i}\left(1-e^{-\lambda_{i}^{w} t_{e}}\right)}{Y_{v} \lambda_{i}^{w}}+\frac{B_{i}^{v}\left(1-e^{-\lambda_{i} t_{b}}\right)}{P \bullet \lambda_{i}}\right] \bullet e^{-\lambda_{i} t_{h}} \\
& \mathrm{C}_{\mathrm{i}}^{\mathrm{S}}=2.0 \mathrm{E}-04 \frac{\mu \mathrm{Ci}}{\mathrm{m}^{2} \mathrm{yr}} \bullet\left[\frac{0.2\left(1-\mathrm{e}^{-(18.1+0.023) 0.192}\right)}{0.7 \frac{\mathrm{kg}}{\mathrm{m}^{2}}(18.1+0.023) \mathrm{yr}^{-1}}+\frac{1 \mathrm{E}-2\left(1-\mathrm{e}^{-0.023 * 38}\right)}{240 \frac{\mathrm{kg}}{\mathrm{m}^{2}} 0.023 \mathrm{yr}^{-1}}\right] \bullet \mathrm{e}^{-0.023^{*} 0.247} \\
& \mathrm{C}_{\mathrm{i}}^{\mathrm{S}}=3.249 \mathrm{E}-06 \frac{\mu \mathrm{Ci}}{\mathrm{kg}} \\
& \mathrm{C}_{\mathrm{i}}^{\text {fodder }}=\mathrm{f}_{\mathrm{p}} \mathrm{f}_{\mathrm{s}} \mathrm{C}_{\mathrm{i}}^{\mathrm{p}}+\left[\mathrm{f}_{\mathrm{p}}\left(1-\mathrm{f}_{\mathrm{s}}\right)+\left(1-\mathrm{f}_{\mathrm{p}}\right)\right] \mathrm{C}_{\mathrm{i}}^{\mathrm{s}} \\
& \mathrm{C}_{\mathrm{i}}^{\text {fodder }}=0.79 * 0.85 * 1.16 \mathrm{E}-06 \frac{\mu \mathrm{Ci}}{\mathrm{kg}}+[0.79(1-0.85)+(1-0.79)] 3.249 \mathrm{E}-06 \frac{\mu \mathrm{Ci}}{\mathrm{kg}} \\
& \mathrm{C}_{\mathrm{i}}^{\mathrm{fodder}}=1.85 \mathrm{E}-06 \frac{\mu \mathrm{Ci}}{\mathrm{kg}} \\
& \mathrm{C}_{\mathrm{i}}^{\text {milk }}=\mathrm{C}_{\mathrm{i}}^{\text {fodder }} \bullet \mathrm{F}_{\mathrm{i}}^{\mathrm{m}} \bullet \mathrm{Q}_{\mathrm{F}} \bullet \mathrm{e}^{-\lambda_{\mathrm{i}} \mathrm{t}_{\mathrm{f}}} \\
& \mathrm{C}_{\mathrm{i}}^{\text {milk }}=1.85 \mathrm{E}-06 \frac{\mu \mathrm{Ci}}{\mathrm{kg}} \bullet 0.3 \frac{\mathrm{d}}{\mathrm{L}} \bullet 6 \frac{\mathrm{kg}}{\mathrm{d}} \bullet \mathrm{e}^{-0.023 * 0.00822} \\
& \mathrm{C}_{\mathrm{i}}^{\mathrm{milk}}=3.32 \mathrm{E}-06 \frac{\mu \mathrm{Ci}}{\mathrm{L}} \\
& \mathrm{D}_{\mathrm{i}}^{\text {milk }}=\mathrm{C}_{\mathrm{i}}^{\text {milk }} \mathrm{U}^{\text {milk }} \bullet \mathrm{DF}_{\mathrm{i}}^{\text {ing }} \bullet 1000 \frac{\text { mrem }}{\text { rem }} \bullet 1 \mathrm{yr} \\
& \mathrm{D}_{\mathrm{i}}^{\mathrm{milk}}=3.32 \mathrm{E}-06 \frac{\mu \mathrm{Ci}}{\mathrm{L}} 230 \frac{\mathrm{L}}{\mathrm{yr}} 5.0 \mathrm{E}-02 \frac{\mathrm{rem}}{\mu \mathrm{Ci}} 1000 \frac{\mathrm{mrem}}{\mathrm{rem}} \bullet 1 \mathrm{yr} \\
& \mathrm{D}_{\mathrm{i}}^{\mathrm{milk}}=3.8 \mathrm{E}-02 \mathrm{mrem}
\end{aligned}
$$




\section{Meat Ingestion Dose}

$$
\begin{aligned}
& C_{i}^{P}=d_{i} \bullet\left[\frac{r_{i}\left(1-e^{-\lambda_{i}^{w} t_{e}}\right)}{Y_{v} \lambda_{i}^{w}}+\frac{B_{i}^{v}\left(1-e^{-\lambda_{i} t_{b}}\right)}{P \bullet \lambda_{i}}\right] \bullet e^{-\lambda_{i} t_{h}} \\
& \mathrm{C}_{\mathrm{i}}^{\mathrm{P}}=2.0 \mathrm{E}-04 \frac{\mu \mathrm{Ci}}{\mathrm{m}^{2} \mathrm{yr}} \bullet\left[\frac{0.2\left(1-\mathrm{e}^{-(18.1+0.023) 0.0822}\right)}{1.8 \frac{\mathrm{kg}}{\mathrm{m}^{2}}(18.1+0.023) \mathrm{yr}^{-1}}+\frac{1 \mathrm{E}-2\left(1-\mathrm{e}^{-0.023^{* 38}}\right)}{240 \frac{\mathrm{kg}}{\mathrm{m}^{2}} 0.023 \mathrm{yr}^{-1}}\right] \bullet \mathrm{e}^{-0.023^{*} 0} \\
& \mathrm{C}_{\mathrm{i}}^{\mathrm{P}}=1.16 \mathrm{E}-06 \frac{\mu \mathrm{Ci}}{\mathrm{kg}} \\
& C_{i}^{S}=d_{i} \bullet\left[\frac{r_{i}\left(1-e^{-\lambda_{i}^{w} t_{e}}\right)}{Y_{v} \lambda_{i}^{w}}+\frac{B_{i}^{v}\left(1-e^{-\lambda_{i} t_{b}}\right)}{P \bullet \lambda_{i}}\right] \bullet e^{-\lambda_{i} t_{h}} \\
& \mathrm{C}_{\mathrm{i}}^{\mathrm{S}}=2.0 \mathrm{E}-04 \frac{\mu \mathrm{Ci}}{\mathrm{m}^{2} \mathrm{yr}} \bullet\left[\frac{0.2\left(1-\mathrm{e}^{-(18.1+0.023) 0.192}\right)}{0.7 \frac{\mathrm{kg}}{\mathrm{m}^{2}}(18.1+0.023) \mathrm{yr}^{-1}}+\frac{1 \mathrm{E}-2\left(1-\mathrm{e}^{-0.023^{*} 38}\right)}{240 \frac{\mathrm{kg}}{\mathrm{m}^{2}} 0.023 \mathrm{yr}^{-1}}\right] \bullet \mathrm{e}^{-0.023^{*} 0.247} \\
& \mathrm{C}_{\mathrm{i}}^{\mathrm{S}}=3.249 \mathrm{E}-06 \frac{\mu \mathrm{Ci}}{\mathrm{kg}} \\
& \mathrm{C}_{\mathrm{i}}^{\text {fodder }}=\mathrm{f}_{\mathrm{p}} \mathrm{f}_{\mathrm{s}} \mathrm{C}_{\mathrm{i}}^{\mathrm{p}}+\left[\mathrm{f}_{\mathrm{p}}\left(1-\mathrm{f}_{\mathrm{s}}\right)+\left(1-\mathrm{f}_{\mathrm{p}}\right) \mathrm{C}_{\mathrm{i}}^{\mathrm{s}}\right. \\
& \mathrm{C}_{\mathrm{i}}^{\text {fodder }}=1.0 * 0.75 * 1.16 \mathrm{E}-06 \frac{\mu \mathrm{Ci}}{\mathrm{kg}}+[1.0(1-0.75)+(1-1.0)] 3.249 \mathrm{E}-06 \frac{\mu \mathrm{Ci}}{\mathrm{kg}} \\
& \mathrm{C}_{\mathrm{i}}^{\text {fodder }}=1.68 \mathrm{E}-06 \frac{\mu \mathrm{Ci}}{\mathrm{kg}} \\
& \mathrm{C}_{\mathrm{i}}^{\text {meat }}=\mathrm{C}_{\mathrm{i}}^{\text {fodder }} \bullet \mathrm{F}_{\mathrm{i}}^{\mathrm{m}} \bullet \mathrm{Q}_{\mathrm{F}} \bullet \mathrm{e}^{-\lambda_{\mathrm{i}} \mathrm{t}_{\mathrm{f}}} \\
& \mathrm{C}_{\mathrm{i}}^{\text {meat }}=1.68 \mathrm{E}-06 \frac{\mu \mathrm{Ci}}{\mathrm{kg}} \bullet 4.0 \mathrm{E}-03 \frac{\mathrm{d}}{\mathrm{kg}} \bullet 36 \frac{\mathrm{kg}}{\mathrm{d}} \bullet \mathrm{e}^{-0.023^{*} 0.0164} \\
& \mathrm{C}_{\mathrm{i}}^{\text {meat }}=2.42 \mathrm{E}-07 \frac{\mu \mathrm{Ci}}{\mathrm{kg}} \\
& \mathrm{D}_{\mathrm{i}}^{\text {meat }}=\mathrm{C}_{\mathrm{i}}^{\text {meat }} \mathrm{U}^{\text {meat }} \bullet \mathrm{DF}_{\mathrm{i}}^{\mathrm{ing}} \bullet 1000 \frac{\text { mrem }}{\text { rem }} \bullet 1 \mathrm{yr} \\
& \mathrm{D}_{\mathrm{i}}^{\text {meat }}=2.42 \mathrm{E}-07 \frac{\mu \mathrm{Ci}}{\mathrm{kg}} 81 \frac{\mathrm{kg}}{\mathrm{yr}} 5.0 \mathrm{E}-02 \frac{\mathrm{rem}}{\mu \mathrm{Ci}} 1000 \frac{\mathrm{mrem}}{\mathrm{rem}} \bullet 1 \mathrm{yr} \\
& \mathrm{D}_{\mathrm{i}}^{\text {meat }}=9.8 \mathrm{E}-04 \mathrm{mrem}
\end{aligned}
$$


WESTINGHOUSE SAVANNAH RIVER COMPANY

\section{APPENDIX C. SAMPLE MAXINE OUTPUT}


MAXINE: A SPREADSHEET FOR ESTIMATING DOSE FROM CHRONIC ATMOSPHERIC RADIOACTIVE RELEASES

\section{DISTRIBUTION (12)}

S. Wood, 773-A

D. B. Moore-Shedrow, 773-A

J.B. Gladden, $773-42 \mathrm{~A}$

G.T. Jannik, 773-42A

P.L. Lee, 773-42A

A. A. Simpkins, $773-42 \mathrm{~A}$

SRTC Records(4), $773-52 \mathrm{~A}$

ED Records(3), $773-42 \mathrm{~A}$ 